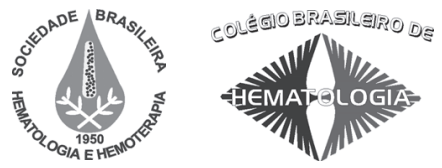

\title{
Carbonyl iron reduces anemia and improves effectiveness of treatment in under six-year-old children
}

\author{
Ferro carbonila reduz anemia e melhora a efetividade do tratamento de crianças menores de \\ 6 anos de idade
}

\author{
Iria L. G. Farias ${ }^{1}$ \\ Elisangela Colpo ${ }^{2}$ \\ Salimara R. Botton ${ }^{3}$ \\ Rosirene B. Silveira ${ }^{3}$ \\ Adriane Fleig ${ }^{4}$ \\ Carlos Andre A. Schimitz ${ }^{5}$ \\ José Edson P. Silva ${ }^{6}$
}

\begin{abstract}
The treatment of iron deficiency anemia in children usually consists in the use of ferrous sulfate solution, but this treatment does not always have the desired effectiveness. The aim of this study was to evaluate the effectiveness of chewable carbonyl iron tablets as an alternative for the treatment of iron deficiency anemia in under six-year-old children. Seventy-three children from Brazilian Family Health Units in Santa Maria, Brazil, were included in this study. One group received chewable carbonyl iron (CI) tablets and a control group received a solution of ferrous sulfate (FS) for 90 days, both at a dose of $5 \mathrm{mg} / \mathrm{Kg} /$ day. Blood was drawn from study participants at 0, 30 and 90 days of treatment to evaluate the whole blood test, ferritin concentration, serum iron, and total iron binding capacity. We also evaluated the acceptance and adherence to treatment, and the occurrence of side effects during treatment. Hemoglobin increased $1.3 \mathrm{~g} / \mathrm{dL}$ in the CI Group and $1.2 \mathrm{~g} / \mathrm{dL}$ in the FS group during the first 30 days of treatment. After 90 days of treatment, the CI Group had significantly better results for hematocrit, $M C V, M C H$, iron binding capacity and ferritin concentration compared to the FS Group. The ferritin concentration was significantly higher in the CI Group at the end of the treatment $(9.51$ $\mathrm{ng} / \mathrm{mL}$ to $26.16 \mathrm{ng} / \mathrm{mL}$ ). Additionally, the treatment was better accepted with fewer adverse effects by this group. Chewable carbonyl iron tablets should be considered an important therapeutic option in the treatment of iron deficiency anemia of under sixyear-old children. Rev. Bras. Hematol. Hemoter. 2009;31(3):125-131.
\end{abstract}

Key words: Iron deficiency anemia; iron carbonyl; ferrous sulfate; children.

\section{Introduction}

Iron deficiency has been considered an important risk factor for ill health, and it is estimated which iron deficiency affects 2 billion people world-wide. ${ }^{1}$ Depletion of iron stores leads to iron deficiency anemia and other serious impairments in the cognitive and intellectual developments. ${ }^{2}$ Treatment of iron deficiency anemia in children usually consists in the use of ferrous sulfate drops, and this treatment sometimes not present the desirable effectiveness. Several studies reported the low treatment adherence due to adverse effects of medication (especially gastrointestinal intolerance and iron

${ }^{1}$ Farmacêutica Bioquímica. Serviço de Hematologia/Oncologia do Hospital Universitário da Universidade Federal de Santa Maria-RS.

${ }^{2}$ Professora da Disciplina de Nutrição do Centro Universitário Franciscano (Unifra) - Santa Maria-RS

${ }^{3}$ Farmacêutica Bioquímica. Laboratório de Análises Clínicas do Hospital Universitário da Universidade Federal de Santa Maria-RS.

${ }^{4}$ Médica. Unidade de Saúde da Família Alto da Boa Vista - Santa Maria-RS.

${ }^{5}$ Médico. Hospital Universitário da Universidade Federal de Santa Maria-RS.

${ }^{6}$ Professor da Disciplina de Hematologia da Universidade Federal de Santa Maria-RS.

Universidade Federal de Santa Maria-RS.

Correspondência: Iria Luiza Gomes Farias

Universidade Federal de Santa Maria, Hospital Universitário, Serviço de Hematologia/Oncologia

Av. Roraima 1000, Campus Universitário

97105-900 - Santa Maria-RS - Brasil

E-mail: irialuiza@smail.ufsm.br

Tel.: (55 51) 3220-8542 - Fax: (55 51) 3220-8591

Doi: $10.1590 / S 1516-84842009005000041$ 
impregnation in the tooth), prolonged daily administration of drops, metallic taste, as well as to cultural aspects. ${ }^{3,4}$ Thus, some aspects should be considered to choose the adequate pharmaceutical preparation, including iron ion content, tolerance, absorption, effectiveness, and cost.

Carbonyl iron powder is obtained through decomposition of Fe pentacarbonyl at high temperatures, and result an extremely pure elemental $\mathrm{Fe}\left(\mathrm{Fe}^{0}\right)$ in the form of non-toxic micro-spheres of 4-7/ $\mu \mathrm{m},{ }^{5}$ with bioavailability $58 \%$ $70 \%$ in relation to ferrous sulfate. ${ }^{6,78}$ Carbonyl iron powder was chosen as raw material especially because it does not give a metallic taste to pharmaceutical preparation, and it presents fewer gastrointestinal adverse effects than ferrous sulfate. ${ }^{9}$

Therefore, it is necessary to investigate new alternatives for iron deficiency anemia treatment, especially for children under six years old, in order to improve the adherence to treatment. The aim of this study was to evaluate the effectiveness of carbonyl iron chewable tablets as an alternative for iron deficiency anemia treatment in children under six years old. We also investigated the acceptance, adherence, and the occurrence of gastrointestinal adverse effects during the treatment.

\section{Patients and Method}

\section{Study population and design}

This is an open, randomized and controlled clinical trial, which utilized ferrous sulfate as iron standard. The studied group was selected randomly, and children included in this group received carbonyl iron (CI), whereas children included in the control group received a solution of ferrous sulfate (FS), both at a dose of $5 \mathrm{mg} / \mathrm{Kg} /$ day, during a period of 90 days. Medication was given to the children one hour before the lunch in both groups. The Ethics Committee of the Universidade Federal de Santa Maria approved this research protocol (number 0052.0.246.000-05). All mothers or legal guardian of the children signed an informed consent to participate in this clinical trial. Seventy-three children with diagnosis of iron deficiency anemia were included in this study. None had received iron orally during 30 days before this study. The following cut-off values were used to determine anemia: hemoglobin $(\mathrm{Hb}) \leq 11 \mathrm{~g} / \mathrm{dL}$; mean corpuscular volume $(\mathrm{MCV}) \leq 75 \mathrm{fl}$; mean corpuscular hemoglobin $(\mathrm{MCH}) \leq 25 \mathrm{pg}$; red cell distribution width (RDW) $\geq 14 \%$; transferrin saturation (TS) $\leq 17 \%$. At least four of these variables would have to be positive for anemia.

\section{Chewable tablets of carbonyl iron}

Chewable tablets of carbonyl iron were produced specifically for this study by Herbarium Laboratório Botânico Ltda (Brazil), in accordance to Good Manufacturing Practices of the National Agency of Sanitary Surveillance (Anvisa, Brazil). Each tablet contained $25 \mathrm{mg}$ of elemental iron. Ferrous sulfate used in this study was obtained from the Ministry of Health from Brazil.

\section{Blood analysis}

Blood samples were collected 0,30 and 90 days after the beginning of treatment. The hemograms were automatically carried out in the Coulter STKS ${ }^{\circledR}$ analyzer (Coulter Electronics, USA). Serum ferritin was measured automatically by immunochemiluminescence assay in the IMMULITE® analyzer (DPC, Los Angeles, USA). Serum iron and total iron binding capacity were measured by use of HITACHI 917® analyzer (Hitachi, Tokyo, Japan). Transferrin saturation was calculated by dividing the concentration of serum iron by the total iron binding capacity multiplied by 100 .

\section{Interview}

A questionnaire containing objective questions was used in an interview with a family member or legal guardian of the child at 30 days after the beginning of treatment. The medication acceptance, treatment adherence, and the occurrence of adverse effects were verified by use of this questionnaire.

\section{Statistics}

Data were analyzed with EpiInfo program, version 3.3.2, of the CDC/USA. ${ }^{10}$ The data were evaluated by analysis of variance (ANOVA) and expressed as mean \pm SEM. Difference between the groups (CI and FS) was evaluated by Student $t$ test, where the difference between the baseline $x 30$ days of treatment and baseline $x 90$ days of treatment in the same group was evaluated by $t$ test. When the variances were not homogenous, ANOVA was not appropriate (Bartlett's P-value $<0.05$ ), so Wilcoxon two-sample test evaluated the data. $\mathrm{P}<0.05$ was considered statistically significant.

\section{Results}

The average age of the studied children was 20 months (minimum of 6 months and maximum of 54 months), where $50 \%$ were $\leq 18$ months. Blood samples of 142 children were collected in order to select the group, and $86(60.56 \%)$ of these had anemia considering the criteria defined in this study. Three children that presented $\alpha$-thalassemia, one that presented non-iron deficiency anemia, and three that presented accentuated eosinophilia were excluded of this study. In relation to 73 children that began the study, 62 returned at day 30 , and 56 completed the 90 days of supplementation.

The studied group $(\mathrm{CI}, \mathrm{n}=38)$ and control group (FS, $\mathrm{n}=35$ ) were selected randomly, and the initial $\mathrm{Hb}$ was $9.37 \mathrm{~g} /$ $\mathrm{dL}$ for CI group and $8.99 \mathrm{~g} / \mathrm{dL}$ for FS group, and no significant differences between the groups were observed. Serum iron, 
Table 1. Baseline values of erythrogram, serum iron, transferrin saturation and ferritin observed in children under 6 years old with iron deficiency anemia that received carbonyl iron chewable tablets ( $\mathrm{Cl}$ group) or a solution of ferrous sulfate (FS group)

\begin{tabular}{cccc}
\hline Measurements & Units & Cl Group $(\mathrm{n}=38)$ & FS Group $(\mathrm{n}=35)$ \\
\hline $\mathrm{RBC}$ & $10 \% \mathrm{LL}$ & $4.62 \pm 0.09^{\mathrm{A}}$ & $4.64 \pm 0.1^{\mathrm{A}}$ \\
$\mathrm{Hb}$ & $\mathrm{g} / \mathrm{dL}$ & $9.37 \pm 0.23^{\mathrm{A}}$ & $8.99 \pm 0.26^{\mathrm{A}}$ \\
$\mathrm{Ht}$ & $\%$ & $29.78 \pm 0.57^{\mathrm{A}}$ & $29.01 \pm 0.68^{\mathrm{A}}$ \\
$\mathrm{MCV}$ & $\mathrm{fL}$ & $65.05 \pm 1.54^{\mathrm{A}}$ & $63.10 \pm 1.65^{\mathrm{A}}$ \\
$\mathrm{MCH}$ & $\mathrm{pg}$ & $20.59 \pm 0.64^{\mathrm{A}}$ & $19.92 \pm 0.68^{\mathrm{A}}$ \\
$\mathrm{RDW}$ & $\%$ & $18.15 \pm 0.60^{\mathrm{A}}$ & $19.48 \pm 0.89^{\mathrm{A}}$ \\
iron & $\mu \mathrm{g} / \mathrm{dL}$ & $27.60 \pm 2.27^{\mathrm{A}}$ & $24.00 \pm 2.14^{\mathrm{A}}$ \\
TS & $\%$ & $7.99 \pm 0.75^{\mathrm{A}}$ & $6.01 \pm 0.51^{\mathrm{A}}$ \\
ferritin & $\mathrm{ng} / \mathrm{dL}$ & $9.51 \pm 1.95^{\mathrm{A}}$ & $10.75 \pm 2.21^{\mathrm{A}}$ \\
\hline
\end{tabular}

Data are reported as mean \pm SEM. Values in the same row that do not share the same upper case superscript letters are significantly different between the groups $\mathrm{FS}$ and $\mathrm{Cl}(\mathrm{P}<0.05$, ANOVA). RBC: red blood count; $\mathrm{Hb}$ : hemoglobin; $\mathrm{Ht}$ : hematocrit; $\mathrm{MCV}$ : mean corpuscular volume; $\mathrm{MCH}$ : mean corpuscular hemoglobin; RDW: red cell distribution width; TS: transferrin saturation.

TIBC, transferrin saturation, and ferritin values also did not vary significantly between the groups. Baseline values observed in both groups were reported in Table 1 .

$\mathrm{CI}$ group presented a hemoglobin increase of $1.3 \mathrm{~g} / \mathrm{dL}$ (minimum value of 0.4 and a maximum of $4.1 \mathrm{~g} / \mathrm{dL}$ ) after 30 days of treatment. There was a hemoglobin increase of $1.2 \mathrm{~g} / \mathrm{dL}$ (minimum value of 0.9 and a maximum of $4.9 \mathrm{~g} / \mathrm{dL}$ ) in FS group. No children presented $\mathrm{Hb}$ decrease in CI group. However, there were three children that presented an $\mathrm{Hb}$ decrease in FS group. There was a 58.6\% favorable response in CI group, and $48.4 \%$ favorable response in FS group, when the increase of $\mathrm{Hb}>1 \mathrm{~g} / \mathrm{dL}$ after 30 days of treatment was considered as a favorable response.

At 30 days, the percentage of children with a high erythrocyte count $\left(\mathrm{RBC}>5 \times 10^{6} / \mu \mathrm{L}\right)$ for $\mathrm{CI}$ group ranged to $24-44 \%$, and this percentage ranged to $25 \%-33 \%$ for FS group. CI group presented a significant difference in $\mathrm{MCH}$ in relation to $\mathrm{RBC}(\mathrm{p}<0.001)$. Fourteen of the 32 children that presented a high erythrocyte count $(>5.106 / \mu \mathrm{L})$ presented lower $\mathrm{MCH}(19.56 \pm 2.7 \mathrm{fl})$, and 18 children with low erythrocyte count $\left(\mathrm{RBC}<5 \times 10^{6} / \mu \mathrm{L}\right)$ presented higher $\mathrm{MCH}(23.31 \pm 2.6 \mathrm{fl})$. No MCH differences were observed in FS group.

The evaluation of pharmaceutical form acceptance indicated favorable results for CI group, and 31 individuals reported a very good acceptance for the following items: flavor, aroma, hardness, size, and pharmaceutical form. In this group, just a child refused the medication (3.12\%), and this occurred 20 days after treatment. A total of $67.3 \%$ of the children from FS group refused to take the medication at some time because they had not liked of drops taste. Probably this finding collaborates for reduction of effectiveness after 90 days. Adverse effects were absent in children of CI group, except for feces darkening. In FS group, $20 \%$ of children presented diarrhea, $36 \%$ experienced vomiting and/or spat out the medication, $6 \%$ experienced vomiting and diarrhea, and $38 \%$ did not present any adverse effect.

Oral ferrous sulfate supplementation in the form of drops was the medical prescription for most of children. Thus, only children who had not been taking ferrous sulfate for at least 30 days participated of this study. Therefore, it was possible to compare both medications. Ease of administration, acceptance by the children in relation to the flavor, a lack of adverse effects, and effectiveness of the treatment were some positive aspects confirmed by children mothers or guardians for $\mathrm{CI}$ group.

There were not significant differences between groups for $\mathrm{Hb}, \mathrm{RBC}$, and RDW after 90 days. Hemoglobin increased from $9.37 \mathrm{~g} / \mathrm{dL}$ to $11.36 \mathrm{~g} / \mathrm{dL}$ in CI group, and from $8.99 \mathrm{~g} / \mathrm{dL}$ to $10.68 \mathrm{~g} / \mathrm{dL}$ in FS group. There were significant differences between the groups for $\mathrm{Ht}, \mathrm{MCH}$ and $\mathrm{MCV}$. We also observed significant differences in ferritin and TIBC levels. In CI group, all variables presented significant differences after 90 days of treatment in comparison to initial values, except for RBC. No significant differences were observed in FS group for RBC, ferritin, and RDW values. There was observed a ferritin increase in CI group at the end of treatment $(9.51 \mathrm{ng} / \mathrm{mL}$ to $26.16 \mathrm{ng} / \mathrm{mL})$. There was also observed a discrete ferritin increase in FS group (10.75 ng/ $\mathrm{mL}$ to $13.41 \mathrm{ng} / \mathrm{mL}$ ). These data was shown in Table 2 and Figure 1. A total of $3.7 \%$ of children from CI group (1/27) continued presenting $\mathrm{Hb}<10 \mathrm{~g} / \mathrm{dL}$ after the end of treatment, whereas this percentage was $31 \%(9 / 29)$ for FS group. A total of $33 \%$ of children in CI group (9/27), and $59 \%$ from FS group (17/29) presented $\mathrm{Hb}<11 \mathrm{~g} / \mathrm{dL}$. Table 3 summarizes some studies that evaluated iron deficiency anemia treatments, and also compare these results with our findings.

\section{Discussion}

This is the first clinical trial that evaluated the effectiveness of carbonyl iron for treatment of iron deficiency anemia in children under six years old. There was not a 
Table 2. Serum iron, TIBC, TS, and ferritin at initial (without treatment) and after 90 days of treatment with $5 \mathrm{mg}$ elemental iron $/ \mathrm{Kg} /$ day in children under 6 years old with iron deficiency anemia that received carbonyl iron chewable tablets ( $\mathrm{Cl}$ group) or a solution of ferrous sulfate (FS group)

\begin{tabular}{cccccc}
\hline \multirow{2}{*}{ Measurements } & \multirow{2}{*}{ Units } & \multicolumn{2}{c}{ FS Group } & \multicolumn{2}{c}{ Cl Group } \\
\cline { 3 - 6 } & & Baseline $(n=35)$ & 90 days $(n=29)$ & Baseline $(n=38)$ & 90 days $(n=27)$ \\
\hline iron & $\mu \mathrm{g} / \mathrm{dL}$ & $24.00 \pm 2.14^{\mathrm{b}}$ & $43.88 \pm 5.23^{\mathrm{A}, \mathrm{a}}$ & $27.67 \pm 2.19^{\mathrm{b}}$ & $44.94 \pm 4.27^{\mathrm{A}, \mathrm{a}}$ \\
TIBC & $\mathrm{\mu g} / \mathrm{dL}$ & $415.17 \pm 17.41^{\mathrm{b}}$ & $321.38 \pm 16.49^{\mathrm{B}, \mathrm{a}}$ & $350.96 \pm 17.61^{\mathrm{b}}$ & $238.77 \pm 9.12^{\mathrm{A}^{* *}, \mathrm{a}}$ \\
TS & $\%$ & $6.01 \pm 0.51^{\mathrm{b}}$ & $16.70 \pm 2.28^{\mathrm{A}, \mathrm{a}}$ & $7.99 \pm 0.75^{\mathrm{b}}$ & $21.78 \pm 2.28^{\mathrm{A}, \mathrm{a}}$ \\
ferritin & $\mathrm{ng} / \mathrm{dL}$ & $10.75 \pm 2.21^{\mathrm{a}}$ & $13.41 \pm 1.74^{\mathrm{B}, \mathrm{a}}$ & $9.51 \pm 1.95^{\mathrm{b}}$ & $26.16 \pm 2.83^{\mathrm{A}^{*}, \mathrm{a}}$ \\
\hline
\end{tabular}

Data are reported as mean \pm SEM. Values in the same row that do not share the same upper case superscript letters are significantly different between the $\mathrm{FS}$ and $\mathrm{Cl}$ groups at 90 days $\left({ }^{*} \mathrm{P}=0.002\right.$ and ${ }^{* *} \mathrm{P}<0.001$, ANOVA). Values in the same row that do not share the same lower case superscript letter are significantly different in the groups, baseline (without treatment) and after 90 days of treatment $(P<0.05$, ANOVA and Wilcoxon two -Sample Test). Iron: serum iron; TIBC: total iron binding capacity; TS: transferrin saturation; ferritin: serum ferritin

significant difference between the groups in relation to effectiveness if only an increase of $\mathrm{Hb}$ after 30 days of treatment was considered a measure of effectiveness. Similar data has been found in other clinical trial by use of carbonyl iron and ferrous sulfate in adults. ${ }^{6}$ We compared the $\mathrm{Hb}$ increase observed in the carbonyl iron group with other studies $^{3,4,11,12,13}$ that utilized other iron sources or other therapeutic strategies, and no important variations were observed, except for study conduced by Pineda et al., ${ }^{12}$ which evaluated a ferrous bys-glycinate chelate treatment, and they observed a significant $\mathrm{Hb}$ increase. Another study ${ }^{13}$ that evaluated the use of prophylactic doses of ferrous sulfate demonstrated a smaller $\mathrm{Hb}$ increase, which reveals the need for greater doses in the iron deficiency anemia treatment. However, it should be considered that initial $\mathrm{Hb}$ in this study was close to the cut-off point for anemia, defined as $11 \mathrm{~g} / \mathrm{dL} .{ }^{13}$ This similarity between our results and those of other studies demonstrates the therapeutic potential of carbonyl iron for the treatment of iron deficiency anemia.

In relation to adverse effects, our data for FS group in relation to diarrhea was similar to other studies, ${ }^{3}$ which reported that $18 \%$ of children experienced diarrhea during the treatment with FS $5 \mathrm{mg} / \mathrm{Kg} /$ day. In this study, there was no variation between daily single doses and the same dose fractioned into 3 daily doses. Other study using a prophylactic amount of $12 \mathrm{mg}$ /day of iron reported that $12.4 \%$ of children experienced diarrhea, which differs from our data possibly due to dose differences. ${ }^{13}$ In relation to vomiting in FS group, mothers reported that it occurred immediately after swallowing. The vomiting could be related to medication flavor, which is difficult to mask at elevated doses. Therefore, the vomiting was grouped together with the refusal to medication swallow, which was the most common adverse effect reported by mothers. Zlotkin et al. ${ }^{3}$ reported that $74 \%$ of children taking FS cried and/or refused to take the medicine.
These data reflect an important aspect that is very favorable for CI group: the children's acceptance of tablet.

These data may corroborate with results observed after 90 days of treatment, where there are observed significant variations between the groups. Although there was not a significant difference in $\mathrm{Hb}$ levels in both groups, there was a significant difference between ferritin and TIBC levels. These data corroborated with a previous study, ${ }^{14}$ which demonstrated the necessity to determine the quantity of corporal iron. The ratio of serum transferrin receptor to serum ferritin was used to better evaluate the impact of iron supplementation, because the determination of $\mathrm{Hb}$ was inappropriate to determine iron status. A patient reevaluation after an intervention by use of ferrous sulfate demonstrated no significant difference in $\mathrm{Hb}$ levels between groups, whereas a difference was easily identified after corporal iron estimation. ${ }^{14}$

The determination of hemoglobin content in the reticulocyte reflects the balance between iron and erythropoiesis, although it is limited by the lower availability of iron to synthesize hemoglobin. ${ }^{15}$ Microcytosis and hypochromia were more severe in patients with high RBC values, regardless of iron status. Iron available per cell in patients with a high erythrocyte count is less than iron available in patients with a low RBC, and a high erythrocyte count may be accompanied by greater microcytosis and hypochromia. ${ }^{16}$ This finding was observed in our study. We also observed an increase in the number of children with high erythrocyte count, as a response to iron supplementation in CI group, and this increase was higher than the increase observed in FS group. As a consequence, there was a small increase in the $\mathrm{MCH}$ level at 30 days. The variables investigated in CI group after 90 days of treatment were very near to cut-off point for anemia, but the $\mathrm{Hb}, \mathrm{Ht}$, serum iron, TS, TIBC, and ferritin exceeded these limits. In FS group, the difference to cut-off point was greater. The mean value of 
RBC

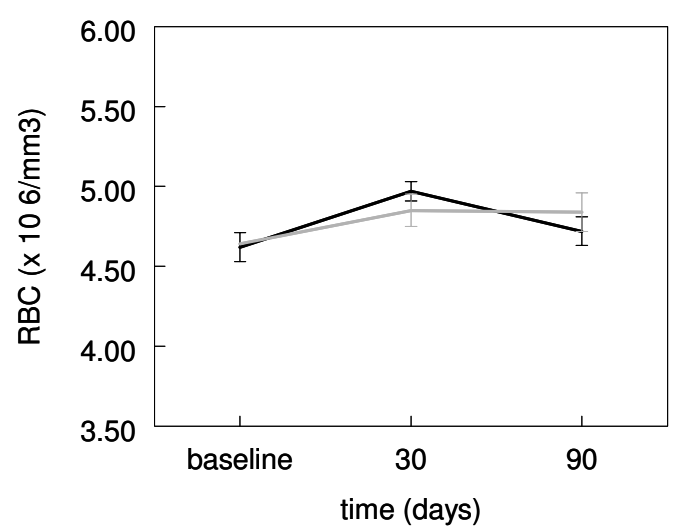

Hemoglobin

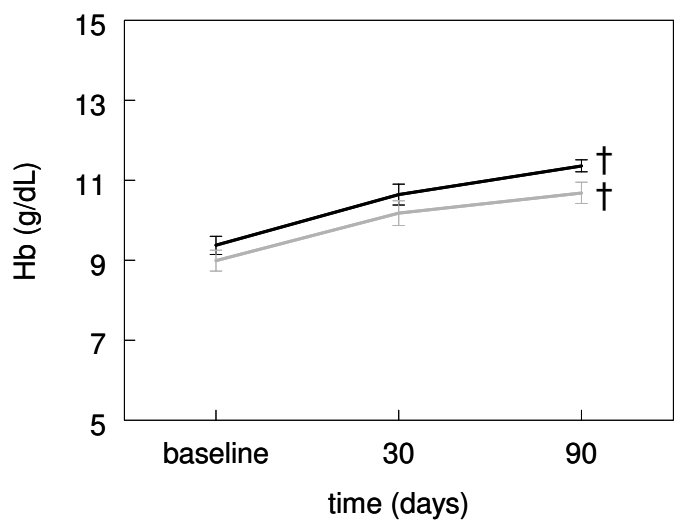

$\mathrm{MCH}$

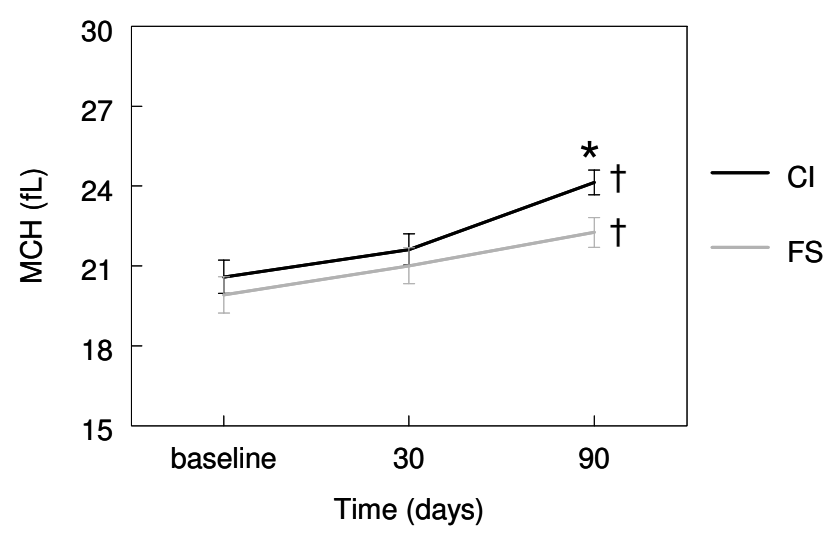

RDW

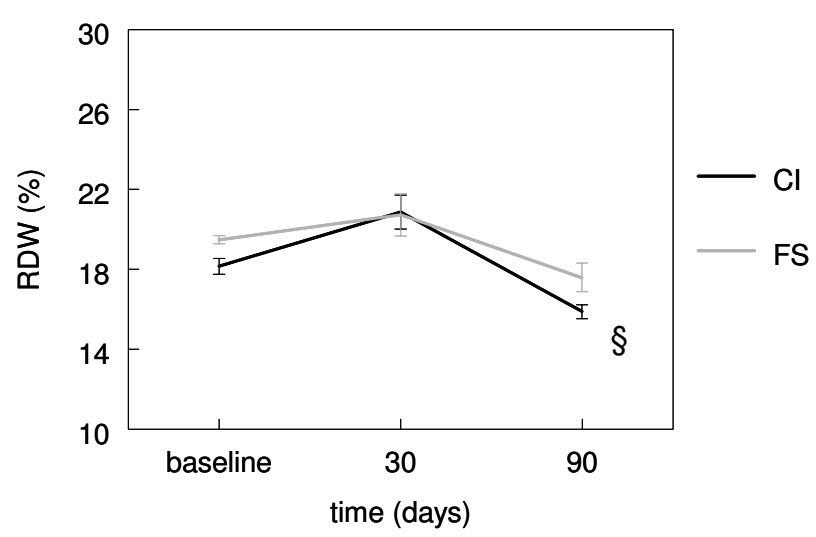

Hematocrit
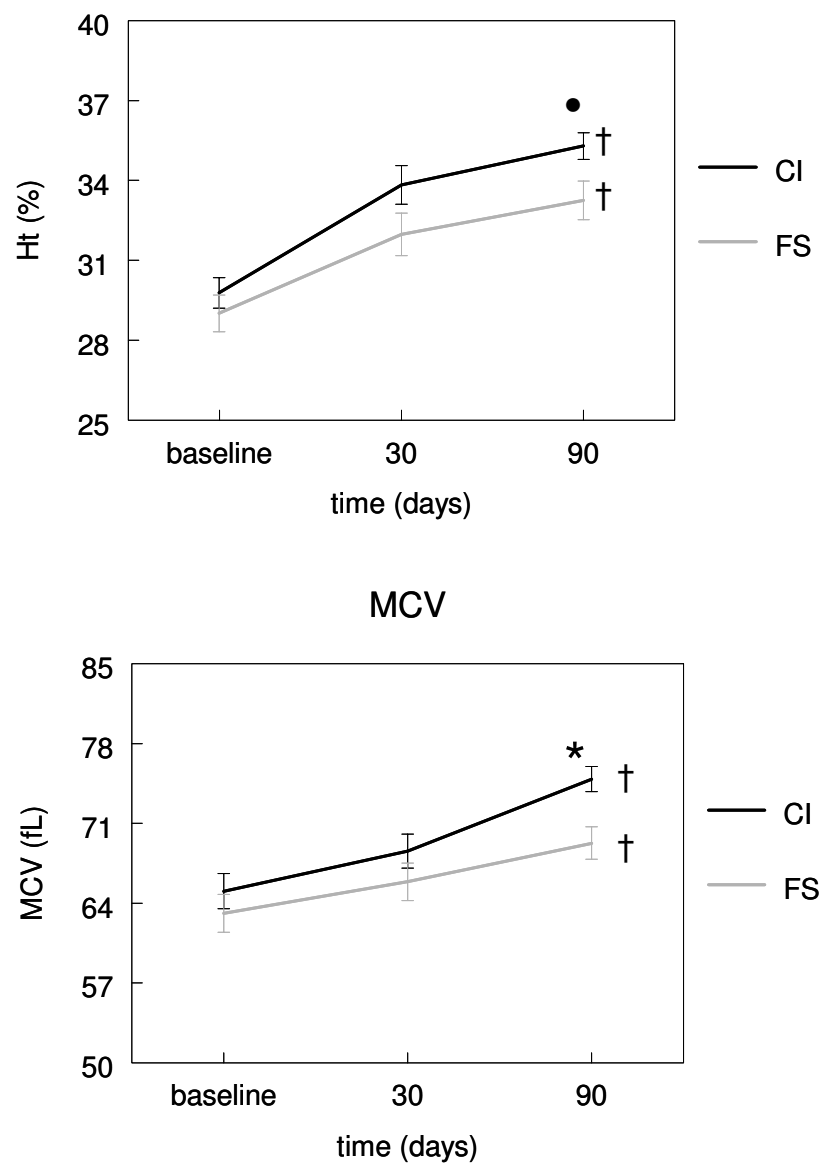

Figure 1. Erythrogram evolution after 30 and 90 days of treatment. Children received carbonyl iron $(\mathrm{Cl})$ or ferrous sulfate (FS), both at dose of $5 \mathrm{mg}$ elemental iron/Kg/day. Data are reported as mean $\pm \mathrm{SEM}$.

- P 0.05 between groups at 90 days of treatment (Wilcoxon Two-Sample Test); * P 0.05 between groups at 90 days of treatment (ANOVA); §P 0.05 baseline versus after 90 days of treatment into same group (Wilcoxon Two-Sample Test); †P 0.001 baseline versus after 90 days of treatment into same group (ANOVA). 
Table 3. Increase of hemoglobin $(\mathrm{IHb})$ as a measure of effectiveness for the treatment of iron deficiency anemia in children. Comparison of the present study with other studies referenced.

$\mathrm{FS}=$ ferrous sulfate; $\mathrm{IHb}=$ increase of $\mathrm{Hb}$ after 30 days of treatment

\begin{tabular}{|c|c|c|c|c|c|}
\hline Clinical Trial & Patients & Drug/dose & $\begin{array}{c}\text { Initial Hb } \\
\text { (g/dL) }\end{array}$ & $\begin{array}{l}\mathrm{Hb} \text { day } 30 \\
(\mathrm{~g} / \mathrm{dL})\end{array}$ & $\begin{array}{c}\text { IHb } 30 \text { days } \\
(\mathrm{g} / \mathrm{dL})\end{array}$ \\
\hline Pineda et al. ${ }^{14}$ & $\begin{array}{l}\text { 6-36 month } \\
\text { old children }\end{array}$ & $\begin{array}{c}\mathrm{FS} 5 \mathrm{mg} / \mathrm{Kg} / \text { day } \\
\text { Fe Bis-glycinate chelate } \\
5 \mathrm{mg} / \mathrm{Kg} / \text { day }\end{array}$ & $\begin{array}{l}8.7 \\
8.0\end{array}$ & $\begin{array}{l}10.5 \\
10.5\end{array}$ & $\begin{array}{l}1.80 \\
2.50\end{array}$ \\
\hline Torres et al. ${ }^{15}$ & $\begin{array}{l}\text { 4-36 month } \\
\text { old children }\end{array}$ & FS $12 \mathrm{mg} / \mathrm{day}$ & 10.6 & 11.28 & 0.68 \\
\hline Zlotkin et al ${ }^{5}$ & $\begin{array}{l}\text { 6-24 month } \\
\text { old children }\end{array}$ & $\begin{array}{l}\mathrm{FS} 5 \mathrm{mg} / \mathrm{Kg} / \mathrm{day}, 1 \mathrm{x} / \mathrm{day} \\
\mathrm{FS} 5 \mathrm{mg} / \mathrm{Kg} / \text { day, } 3 \times / \text { day }\end{array}$ & $\begin{array}{l}8.8 \\
8.7\end{array}$ & $\begin{array}{l}10.2 \\
10.0\end{array}$ & $\begin{array}{l}1.4 \\
1.3\end{array}$ \\
\hline Schultinket al. ${ }^{6}$ & $\begin{array}{l}2-5 \text { year } \\
\text { old children }\end{array}$ & $\begin{array}{c}\text { FS 30mg Fe, } 2 x / \text { week } \\
\text { FS } 30 \mathrm{mg} \text { daily }\end{array}$ & 10.8 & 11.4 & 0.60 \\
\hline Zlotkin et al. ${ }^{13}$ & $\begin{array}{l}6-18 \text { month } \\
\text { old children }\end{array}$ & $\begin{array}{l}\text { Ferrous fumarate } \\
5 \mathrm{mg} / \mathrm{Kg} / \text { day } \\
\text { FS } 5 \mathrm{mg} / \mathrm{Kg} / \text { day }\end{array}$ & $\begin{array}{l}8.7 \\
8.7\end{array}$ & $\begin{array}{l}10.2 \\
10.0\end{array}$ & $\begin{array}{l}1.5 \\
1.3\end{array}$ \\
\hline Present study & $\begin{array}{l}5-72 \text { month } \\
\text { old children }\end{array}$ & $\begin{array}{l}\mathrm{FS} 5 \mathrm{mg} / \mathrm{Kg} / \text { day } \\
\mathrm{Cl} 5 \mathrm{mg} / \mathrm{Kg} / \text { day }\end{array}$ & $\begin{array}{l}8.99 \\
9.37\end{array}$ & $\begin{array}{l}10.18 \\
10.64\end{array}$ & $\begin{array}{l}1.19 \\
1.27\end{array}$ \\
\hline
\end{tabular}

ferritin in CI group ( $26.16 \mathrm{ng} / \mathrm{mL}$ ) was two-fold compared to FS group $(13.41 \mathrm{ng} / \mathrm{mL})$, and this difference may reflect better results of hematological values $(\mathrm{MCV}, \mathrm{MCH})$ observed in this group.

In relation to treatment effectiveness after 90 days, the number of children from control group that continued to present hemoglobin level lower than $11 \mathrm{~g} / \mathrm{dL}$ was two-fold in comparison to the group that received carbonyl iron. Our results with carbonyl iron demonstrated the same effectiveness at 30 days of standard ferrous sulfate treatment, and better results at 90 days of treatment, together with excellent acceptance. These data added to the safety (low toxicity) allow concluding that carbonyl iron constitutes an important option for therapeutic treatment of iron deficiency anemia in children under six years old; moreover its use could be considered as an alternative for public health prevention programs.

\section{Resumo}

O tratamento da anemia ferropriva de crianças consiste, em sua maioria, no uso de solução de sulfato ferroso e este tratamento nem sempre apresenta a efetividade desejada. O objetivo deste estudo foi avaliar a efetividade do ferro carbonila, na forma de comprimidos mastigáveis, como uma alternativa de tratamento para anemia ferropriva de crianças menores de seis anos de idade. Foram incluídas no estudo 73 crianças atendidas em PSFs de Santa Maria, RS. Um grupo recebeu comprimidos mastigáveis de ferro carbonila (CI) e o grupo controle recebeu solução de sulfato ferroso (FS), ambos a dose de $5 \mathrm{mg} / \mathrm{kg} /$ dia por 90 dias. Amostras de sangue foram coletadas nos dias zero, 30 e 90 do tratamento para avaliação de hemograma, ferritina, ferro sérico e capacidade total de ligação do ferro. Também foi avaliada a aceitação e aderência ao tratamento e relato de efeitos colaterais durante o tratamento. A hemoglobina teve um incremento de $1,3 \mathrm{~g} / \mathrm{dL}$ no grupo CI e 1,2g/dL no grupo FS aos 30 dias de tratamento. Após 90 dias de tratamento, o grupo CI apresentou resultados significativamente melhores para hematócrito, VCM, HCM, CTLF e ferritina. A ferritina do grupo CI teve um importante aumento ao final do tratamento $(9,51 \mathrm{ng} / \mathrm{mL}$ para 26,16ng/mL). O grupo CI apresentou melhor aceitação do tratamento e menos efeitos colaterais. Comprimidos mastigáveis de ferro carbonila poderiam ser considerados uma importante opção terapêutica para tratamento da anemia ferropriva de crianças menores de seis anos de idade. Rev. Bras. Hematol. Hemoter. 2009; 31(3):125-131.

Palavras-chave: Anemia ferropriva; ferro carbonila; sulfato ferroso; crianças.

\section{References}

1. World Health Organization. Reducing risks, promoting health life. The World Health Report. Geneva, Switzerland: World Health Organization, 2002.

2. Grantham-McGregor S, Ani C. A review of studies on the effect of iron deficiency on cognitive development in children. J Nutr. 2001;131(2S-2):649S-666S.

3. Zlotkin S, Arthur P, Antwi KY, Yeung G. Randomized, controlled trial of single versus 3-times-daily ferrous sulfate drops for treatment of anemia. Pediatrics. 2001;108(3):613-6.

4. Schultink W, Gross R, Gliwitzki M, Karyadi D, Matulessi P. Effect of daily vs twice weekly iron supplementation in Indonesian preschool children with low iron status. Am J Clin Nutr. 1995;61 (1):111-5.

5. Food and Drug Administration. Iron-containing supplements and drugs: label warning statements and unit-dose packing requirements. Federal Register 21CFR parts 101,111 and 310. January 15, 1997. 
6. Hoppe M, Hulthen L, Hallberg L. The relative bioavailability in humans of elemental iron powders for use in food fortification. Eur J Nutr. 2006;45:37-44.

7. Devasthali SD, Gordeuk VR, Brittenham GM, Bravo JR, Hughes MA, Keating LJ. Bioavailability of carbonyl iron: a randomized, double-blind study. Eur J Haematol. 1991;46(5):272-8.

8. Sacks PV, Houchin DN. Comparative bioavailability of elemental iron powders for repair of iron deficiency anemia in rats. Studies of efficacy and toxicity of carbonyl iron. Am J Clin Nutr. 1978; 31(4):566-71.

9. Gordeuk VR, Brittenham GM, McLaren CE, Hughes MA, Keating LJ. Carbonyl iron therapy for iron deficiency anemia. Blood. 1986;67(3):745-52.

10. Dean AG, Dean JA, Burton AH, Dicker RC. Epi Info: a generalpurpose microcomputer program for public health information systems. Am J Prev Med. 1991;7(3):178-82.

11. Zlotkin S, Arthur P, Antwi KY, Yeung G. Treatment of anemia with microencapsulated ferrous fumarate plus ascorbic acid supplied as sprinkles to complementary (weaning) foods. Am J Clin Nutr. 2001;74(6):791-5.

12. Pineda $\mathrm{O}$, Ashmead HD. Effectiveness of treatment of irondeficiency anemia in infants and young children with ferrous bisglycinate chelate. Nutrition. 2001;17(5):381-4.

13. Torres MA, Sato K, Juliano Y, Queiroz SS. Treatment with prophylactic doses of ferrous sulphate in the fight against iron deficiency in children attended in basis health units. Rev Saude Publica. 1994;28(6):410-5.

14. Cook JD, Flowers CH, Skikne BS. The quantitative assessment of body iron. Blood. 2003;101(9):3359-64.

15. Brugnara C, Zurakowski D, DiCanzio J, Boyd T, Platt O Reticulocyte hemoglobin content to diagnose iron deficiency in children. JAMA. 1999;281(23):2225-30.

16. Aslan D, Altay C. Incidence of high erythrocyte count in infants and young children with iron deficiency anemia: re-evaluation of an old parameter. J Pediatr Hematol Oncol. 2003;25(4):303-6.

Avaliação: Editor e dois revisores externos

Suporte Financeiro: CNPq, Fundação Herbarium de Saúde e Pesquisa.

Recebido: 09/05/2008

Aceito após modificações: 24/11/2008 